\begin{tabular}{c} 
Volume and Issues Obtainable at Center for Sustainability Research and Consultancy \\
Journal of Accounting and Finance in Emerging Economies \\
ISSN: 2519-0318 ISSN (E) 2518-8488 \\
Volume 5: Issue 2 June 2019 \\
CSRᄃ \\
Journal homepage: www.publishing.globalcsrc.org/jafee \\
\hline
\end{tabular}

\title{
The Maqasid Al Shariah and the Sustainability Paradigm: Literature Review and Proposed Mutual Framework for Asnaf Development
}

\author{
${ }^{1}$ M Ashraf Al Haq, ${ }^{2}$ Norazlina Abd Wahab \\ ${ }^{1} \mathrm{PhD}$ candidate, IBS, Universiti Utara Malaysia. glinklondon@gmail.com \\ ${ }^{2}$ Senior Lecturer, IBS, Universiti Utara Malaysia.norazlina.aw@uum.edu.my
}

\begin{tabular}{l}
\multicolumn{1}{c}{ ARTICLE DETAILS } \\
\hline History \\
Revised format: Novembetr 2019 \\
Available Online: December 2019 \\
\\
\hline Keywords \\
Zakat, Poverty Alleviation, \\
Sustainability Development, \\
Maqasid Al Shariah
\end{tabular}

JEL Classification:

$Q 01, I 32, B 1$

ABSTRACT

Purpose - The study examines through analysing the literature, that the zakat recipients (asnaf) can be better entertained by a sustained mechanism than one-off measures. The main aim towards asnaf upliftment should be based on a self-reliance goal-oriented-action strategy plan to alleviate them from any further deprivation. The aim of Maqasid in addressing these issues is to ensure that an asking basket gets smaller day by day through an effective regime.

Design/Methodology/Approach - The paper analyses and synthesises the relevant literature on Maqasid and sustainable paradigm, then proposes a conceptual convergence to understand the paradigmatic similarities between the two in appreciating the welfare of zakat recipients.

Findings - The paper attempts to examine the latitude of sustainability and Maqasid necessities in relation to asnaf welfare. The sustainability development's main concern that the future generation benefits from the present development, which is quite similar to Hifzul Nasl or protection of progeny in Maqasid fulfilment. It can be stated that the three jurisdictions of sustainable development (SD) paradigm i.e., namely, the social, economic and environmental concerns are in actual fact, more in conformity with the Maqasid requirements. But many authors stated that indeed Maqasid is more wholesome and more encompassing than the traditional SD paradigm. Islam categorically highlights that human being as a caretaker of environment, need to ensure a better, and harmonious society, that should be erected with constructive and productive economic activities and not resorting to any damages to the nature. These concerns clearly conforms with Maqasid when it conditions that the protection of life or health, or intellect or progeny or wealth needs to be with true understanding about the self as well as the kindness of the creator, which truly encompasses faith, and that to achieve any higher dimension, may require that these basic necessities are fulfilled and ascertained at the foremost.

Originality/value - This study scrutinises a comprehensive understanding about sustainability and Maqaisd needs in addressing the asnaf development and welfare. The study further elucidates that even the nature is in constant salutation towards thanking the Lord for all the bounties.

(C) 2019 The authors, under a Creative Commons Attribution-Non Commercial 4.0 
Corresponding author's email address: glinklondon@gmail.com

Recommended citation: Haq,M.A.A. and Wahab, N.A., (2019). The Maqasid Al Shariah and the Sustainability Paradigm: Literature Review and Proposed Mutual Framework for Asnaf Development. Journal of Accounting and Finance in Emerging Economies, 5 (2), 179- 196

DOI: $10.26710 /$ jafee.v5i2.854

\section{Introduction}

The asnaf (i.e. the zakat recipients) need a steady development that is sustainable and not necessarily just one-off measures, so that they can withstand adversities and be self-reliant within a time frame with the necessary help, assistance, support and motivation (Abdullah, 2012; Haq et al., 2017; Obaidullah et al., 2014). The implementation of the Maqasid (reasoning and the rational) of the Shariah is to ensure that the asking basket is reducing over time, as was witnessed in Khalifatul Rashideen (righteous Caliphs) time (Nadzri et al., 2012). In conventional wisdom, the sustainability paradigm encompassing the three top requirements, i.e. first the ecological balance, keeping in view the social progression and achieving and advancing the economic emancipation - is somewhat overriding in addressing the woes of downtrodden people such as the asnaf who many need gradual and sustainable support and development to keep their means at developing ends (Ali et al., 2014; Ibrahim, 2015; Yumna et al., 2011).

The wellbeing is the key to achievements, and the Maqasid which means 'in the end' as per Laldin et al. (2013) is the key to happiness, comfort and satisfaction (Rasool et al., 2018). In Islamic perspective, the Maqasid Al Shariah encompassing the five exegeses of protections, such as life, belief, honour, intellect and property, which in other words, give a peaceful, clean, and decent living i.e. Hayat-e-Tayyaba (Rasool et al., 2018), may be enormously indispensable in terms of long term comfort and sustenance.

According to Ahmadi (2016), the sustainable development (SD) in Islamic perceptive is based on understanding that the role of human being is based on responsibility and to care for the nature, and it depends on mainly in safeguarding the benefits to all spectrum including the animal kingdom and the environment. According to the Islamic appreciation as per Ahmadi (2016), humankind is not the owner, but only the meagre manager to ensure upkeep in most judicious way, as the mankind is entrusted to ensure wisdom and civility in every way in terms of bringing harmony to greater society, nature and the human life. In addition, Ahmadi (2016 quoting Al-Jayyousi, 2015) stated that wastage is strictly forbidden in an Islamic society, because Islam disallows unscrupulous depletion and degradation to the environment, and failing to protect the environment is rather a failure of mankind in guardianship towards being honest steward of the nature. The author (Ahmadi, 2016) further pointed that species are constantly in prayers (Tasbeeh) as stated in Holy Scriptures and rightly pointed to avoid environmental corruption which may be not astute for true proponents of development.

Ahmadi (2016) further quotes Nouh (2012) in making a stand towards not jeopardising the rights of future generations for the present consumptive nature of human, as ascertained by the sunnatic traditions. Laldin et al. (2013) added that the goal of Maqasid Al Shariah is to illustrate a preferred direction of all human actions, and that is towards 'siratul mustaqim' (right direction), and it's toward peaceful and progressive environment.

The paper has few parts. At the initial level, the study will attempt to elucidate in detail the different aspects of sustainable development and the Maqasid facets through analogy and review of the comprehensive literature, and then will attempt to explain different measurement techniques, and issues. Furthermore, the convergence and significance of the two broad paradigm, and will put forward a conceptual framework and will finally draw the concluding remarks, discussions and recommendations.

\section{The Paradigmatic Mutualities and Differences}

The similarities and differences do exist between the two paradigms, though both are for betterment of human development and welfare. Discussed briefly below.

\subsection{What is Sustainable Development and why it is Important in Present Context?}

According to Strange et al. (2008), the persistent development has costs, which one can hardly ignore. Mere economic prosperity cannot solve societal and environmental issues and stop any level of degradation, for which the nations need to address the rising inequality and concentration of wealth in the hands of few (Hasan, 2006). Therefore, sustainable development, as per the above authors, is about integration and understanding the potential impacts of each action, and more profoundly impacts on the future. Quoting Brundtland Report (1987), the authors 
state that sustainable development 'meets the needs of the present without compromising the ability of future generations to meet their own needs'.

The need for sustainable development became important since unprecedented growth started taking place relentlessly across different territories (Redclift, 1989). But if this development is not sustainable then issue crops up in relation to ethical, ecological, societal, and matters that may require necessary and often crucial remedy (Hasan, 2006). So keeping in line to that requirement, the initial Brundtland Report, in October, 1987 and further more in 1998, Elkington's proposed basic three dimensional paradigms naming the triple bottom line in view of sustainable development, are testimony that the non-financial measures are equally as important as financial ones. This concept evolved as a renewed yardstick worldwide in appreciating human, social and economic development. keeping in view the utmost safe keep of the fragile environment.

The importance of sustainable development became important in the modern context is due to the need for understanding the non-economic measures in appreciating development. Before the advent of SD, the development and growth meant only reporting financial indices and the need to calculate the margin of profit of the firm. But the emergence of SD has brought few checks in terms of development as the need to take the social and environmental concern along with economic development has gained and further gaining importance and maintaining that status quo. Similarly in case of asnaf development, the non-financial woes, such as capability, natural, human and social assets and so on - are acknowledged as equally important, as seen in few findings (Kamarruddin et al., 2014). Therefore, according to Brugmann (1997), the sustainability of economic development at present truly depends on solving the environmental and social worries.

According to Kamaruddin et al. (2014), its important to address the ability, capacity and the preparedness for shocks in addition to income and assistance parameters. The authors describe the scenario through an English proverb, where, if a man is given a fish every day, he might remain dependent for long, but if he is taught how to catch a fish, then that may give him to withstand for life.

\subsection{Understanding Maqasid Al Shariah in the Context of Sustainable Development}

In elaborating the multidimensional process of sustainable development from Islamic perspective, Nouh (2012) states that Islam drives a balance between economic and social development in one side and the environmental importance on the other side, to maintain efficient and effective resource usage. Because Allah proclaims in the Holy Scriptures, "And there is no creature on [or within] the earth or bird that flies with its wings except [that they are] communities like you. We have not neglected in the Register a thing. Then unto their Lord they will be gathered" (Al Qur'an 6:38). Furthermore, the author (Ahmadi, 2016) explains from Quran, "...you will have upon the earth a place of settlement and provision for a time" (Al Qur'an 2:36) which directs humans to follow a disciplined and planned living for maintaining harmony.

According to Alam et al. (2018) Islam encourages community wellbeing as an important aspect in terms of attaining Islamic sustainability or the Maqasid. Islam prioritises the importance of attaining better living condition including education, targeting improved healthcare for the masses, and care for the ecological balance in realising the Maqasid. In answering these objectives, Alam et al. (2018) quoted that even the father of economics, Sir Adam Smith (1937) argued for effective resource utilisation towards the welfare of the mankind. By addressing the community's welfare, it is expected that it will in turn direct the individuals and the greater concerns, and may most likely bring overall benefit in the economy through prosperity and harmony. This in turn may ensure economic sustainability, as explained by Alam et al. (2018). In Islam, welfare of mankind is in other words the Lord's serving dictum and that is the nexus of any development initiative in an Islamically inspired Maqasid attainments.

Islamic system bases its argument on reforming human welfare, as per Maqasid, as opposed to profit agenda as propagated by conventional wisdom (Alam et al., 2018; Dusuki et al., 2011). This refined welfare system is a further testimony to balance and ensure ethical primacy (Naqvi, 1981 as cited by Alam et al., 2018) for all the stakeholders based on trust, equity and excellence (Alam et al., 2018; Hassan et al., 2010). According to Alam et al. (2018) and many others, the Islamic welfare maximisation can be envisioned when inner self development is realised only through a thorough concerted effort. In return, society benefits resultantly the equitable distributive mechanism along with environmental enrichment, or in plain words safety for the nature at a harmonious level. This value based ethical and effective system, according to Alam et al. (2018) can align the system as per Myrdal's 
societal developmental vision, and can bring true harmony to society. This shared understanding can lead to a win win situation for both the proponents of Maqasid and the sustainable development SD.

As per Kamali (2011), in pursuing Shariatic goals under the auspices of Maqasid, there are three main objectives that can be attained, i.e. mercy of mankind, benefits to greater nature and all species, and removing any harm to entities, in other words, ensuring public benefit or interest (Maslahah for Ummah). In Islam, Maslahah rather aims to protect humans, society and the fragile nature. Imam Ghazzali, rightly classified that to protect the religion or belief (hifzu Deen) -there are four Duniyawi (worldly) activities that are important, i.e. protection of life (nafs), lineage (nasl), intellect ('aql), and wealth (maal) (Abubakar, 2016). But according to Imam Qarafi, protection of dignity (ird) is equally important in safeguarding oneself (Abubakar, 2016). And not to mention that the Maqasid al Shariah can overpoweringly assist in social reasonability agendas of individual, society and the nation in pursuit of wellbeing and benefit of all (Arsad et al., 2015).

\subsection{The Difference between Conventional Wisdom and Islam}

Alternatively, Islamic understanding is to be at a moderate (wasat) level in all aspects (Kamali, 2011). As per Chapra (2008) and Mohammad (2010), Islam propagates neither laissez faire nor totalitarian view. It rather encourages harmony with nature and a system more atoned towards welfare for all, avoiding resource exploitation and wastage (Mohammad, 2010). In line with Ibn Khaldun (Chapra, 2008) and Muhammad (2010), the national economy essentially grows with wellbeing of the masses, and removing hardship. Public spending on empowerment of the poor and rebuilding the infrastructure, like disbursements more on health, education and spirituality - enhances skills, social as well as distributive justice, and gives rise to civilisational development and well-management of the economy and nation. Ibn Khaldun is rather called the true father of economics and economic theory because of his understanding of the institutional interconnectivity which may lead to economy to rise or fall. He understood and explained the income, expenditure and the multiplier effect long before the theories came into place (Chapra, 2008; Mohammad, 2010; Soofi, 1995). A point to note by Ibn Khaldun is that - the sustainability may not be an issue if the masses or the grassroots income remains above the poverty line, reported by Mohammad (2010).

Islamic teaching and lifestyle promotes wellbeing and happiness for all irrespective of colour or race or religion (Chapra et al., 2008). Qur'an states, "We have sent you forth as nothing but mercy to people of the whole world" (Al Qur'an 21:107). Chapra et al. (2008) further clarifies, that sustained growth is a necessity in drives towards an equitable society, where all are better off. The authors, further records, quoting Qur'an, "Allah does not change the condition of a people until they change their own inner selves" (Al Qur'an 13:11). In other words, its Lord's commandment to improve, but for the better, and for all, and not for only the few. Islam accepts enrichment or profiting but not at the expense of disregarding the social responsibility (Dusuki et al., 2007). Therefore, through the Maqasid, Islam promotes social cohesiveness and growth in economy through ethical and rational expansion, and safeguarding the nature, as per Dusuki et al. (2007).

According to Ibrahim et al. (2010) the sustainable development encompasses the understanding of well-being of human as well as nature through integrating social development, economic development and environmental conservation as well as protection. According to the said authors, social development means emancipation of human rights, like access to education, healthcare, food, housing, equitable employment and so on. Likewise, economic development truly means that the availability of work and the ability of individuals to secure income to support their families (Ibrahim et al., 2010). And these are the basic qualities enshrined even in an Islamically inspired Maqasid framework (Ibrahim et al., 2010). Therefore, the basic objectives of Shariah are to put emphasis on welfare of the people and their 'relief from hardship' (Ibrahim et al., 2010).

As per Hasan (2006) and Ibrahim et al. (2010) the concept of sustainable development has three important aspects, primarily, the concept of long run growth rather than short term plans, secondarily, understanding about intergenerational equity in the use of natural resources, and thirdly, restricting as far as possible the pollution level for maintaining the quality of environment. Ibrahim et al. (2010) highlighted the need of safeguarding the nature and ensuring the betterment of the 'future generations', as that was emphasised in the Brundtland report (1987). But such protection measures for future generations are actually the hallmarks of Maqasid, as duly stated in Hifzu Nasl or protection of progeny (Abubakar, 2016). In 2002, the Islamic conference of environment minsters made the Islamic Declaration on Sustainable Development, where economic growth and understanding of the resource constraints were highlighted, while safe use was genuinely promoted (Ibrahim et al., 2010). In addition, the Islamic 
viewpoint embraces the spiritual upliftment to maintain a dignified status of fellow believers, because that will ensure protection of faith, self and honour (Ibrahim et al., 2010; Chapra et al., 2008; Hasan, 2006).

Hasan (2006) prioritises the vitality of non-material (spiritual) needs as the material ones so as to lead a healthy state. Hasan (2006) addresses further that after Agenda 21 in Rio (1992), the renewed emphasis on social justice, on recycling initiatives and on conserving the environment - enforces the notion that material as well as non-material (spiritual) development are important, and hence the sustainable development in the conventional paradigm in the end (and in essence) conforms to Maqasid requirements. Human may heed to Lord Almighty's warning, "Evil has become rife on the land and at sea because of men's deeds" (Al Qur'an 30:41). So through this improved understanding after the Agenda 21, it's obvious that the modern notion of sustainable development is more towards ethical and balanced development.

In Islamic paradigm, According to Alam et al. (2015), the Islamic set of principles guided by Maqasid is to attain Masalih (betterment) in society (Dusuki et al., 2011). The Maqasid set of laws answers the questions linked to why and how in relations to Shariatic applications. Therefore, this Maqasid enshrines the conventional wisdom as stated by Maslow on his hierarchic theory, where self-actualisation is the prime goal in achieving highest standard in attainment of life (Ahmed et al., 2011; Alam et al., 2015; Bakar et al., 2011; Dusuki et al., 2011).

The proponents of Maqasid, like Imam Al-Shatibi and Imam Al-Ghazzali constructed three tier of Maqasid hierarchy in order to measure it, and that is - Al-daruriyyat (necessity), Al-hajiyyat (the complements or supports) and Al-tahsiniyyat (embellishments), where Al-daruriyyat relates to absolute necessity. Furthermore, Al-daruriyyat has five subsections (Alam et al., 2015; Dusuki et al., 2011), namely, protection of faith - i.e. seeking truth and justice, protection of life through well-being, protection of Intellect through knowledge enhancement, protection of linage and honour through fulfilling obligations towards future generations and finally protection of wealth through ensuring economic justice and peace. Nevertheless, many scholars such as Nadzri et al. (2012) addresses that the asnafs' basic need fulfilment is actually the top most priority in getting them out from the asking basket.

\section{How to Measure the Maqasid al Shariah}

The purpose of ensuring the Maqasid is to secure benefit to all stakeholders, without harming any one (Azhar Rosly, 2010; Kamali, 2011). Therefore, in pursuit of measuring the Maqasid, it is to ensure the protection of basic necessities (Al Daruriyat), which encompasses faith, life, progeny, intellect and property. As for example, the prohibition of interest in Islam is for instance like not harming any party, because one can lose all his property due to unfair means, such as cumulative interest charges (Azhar Rosly, 2010). Qur'an promotes healthy and sustainable business activities, while forbidding to rely on interest earning in the economy (Al Qur'an 2:275), so as to repel harm from society. Islam encourages having mutually beneficial contracts, and asks for up-keeping them.

So once the basics are addressed in order, then the need to take attention towards the Hajiyat and Tahsiniyat comes in question. According to Abubakar (2016), the hajiyyaat are important, but its absence may not warrant a chaos in society, and may only lead to hardship and difficulty. As for example, a validity of a hire agreement is an important matter and is necessary to the hirer, but may not be an issue for everyone. Often in a conflict of interest, a higher priority given due recognition while lesser one is given a sad sacrifice. Another example is that to accustom the believers in understanding the importance of charity, and even if that person has nothing to offer, maybe he lends a smile or similar and that should be encouraged as per Prophetic tradition, though nothing tangible was given to fulfil an obligation (Abubakar, 2016). And in case of Tahsiniyat, it is to seek considerable improvement and perfection in conducts and customs of people at all ranks, so as to make society a better place, according to the said author.

\subsection{How Maqasid is Linked to Personal Development}

According to Mili (2014), ethics constitutes personal development in an Islamic framework. The author in pursuit of understanding the impact of Maqasid on human development did a thorough empirical analysis, where the author found that protecting life through spiritual development is important towards maintaining a good self. The author states, "Unlike the secular market paradigm, human well-being in Islam does not depend essentially on the maximisation of wealth and consumption". It requires a balanced approach in maintaining stability between healthy material and spiritual development. The author further states, the five pillars of Islam, namely having faith, saying the prayer, fasting in the designated month, executing the pilgrimage, and paying alms, may not necessarily ensure 
that ethical self has developed, but rather reforming the behavioural aspects in accordance to Islamic understanding which is designed to realise the Maqasid, namely social-economic justice and wellbeing for all, can ensure a more favourable outcome.

The author (Mili, 2014) clarifies that frustrations in society or criminal activities in society may be more due to lack of understanding of the spiritual need in maintaining a healthy life. So, Sulayman (2014) gave some rationale for integrating moral values in school curriculum so that ethically enriched students may perform better in terms of attaining worldly and spiritual life. The value-based system can enhance students in terms of suppressing the evil considerations and ultimately concentrate more on ethical and healthy development. Lord proclaims, "And do not make mischief in the earth after it has been set in order, and call upon Him with fear and longing. Surely Allah's mercy is close to those who do good (Al Qur'an 7:56). Consequently, it's natural that the goals of Maqasid is to edify the individual self, and to create a social structure and environment based on moral values, where effective economic reform is based on ethical development (Mili, 2014).

Chapra (2008) proposed a comprehensive theoretical framework on personal development based on Maqașid alShariah (Mili, 2014). Similarly Mili (2014) elaborated the impact of Maqasid on human well-being and overall development. Correspondingly Dar (2004), developed the Ethics-Augmented Human Development Index (HDI-E), and Anto (2011) suggested a human development index based on Maqașid al-Shariah, where environmental concerns gained priority in similar manner (Mili, 2014).

\section{Maqasid al Shariah and the Broader Dimensions of Sustainable Development}

According to Nalla (2011) the worldview in Islamic arena inextricably includes social responsibility at the core under the strict guidance of Qur'an and the Sunnah. Therefore, these revealed sources guide the Muslims in developing and refining their Akhlaq (morality and ethics) through regular prayers (Ibadah) and having stronger Aqeedah (creed), and helping the mankind for a better world. So through remembering the three main dimensions of social, economic and environmental concerns, Islam inspires the believers in economic development keeping in view firmly the social justice note in mind, as ordained in Qur' an, "God commands you to do justice and be fair [to others]" (Al Qur'an 16: 90). Accordingly this social reminder clarifies the Islamic viewpoint and the necessary injunctions in regards to society and nation development, and it becomes evidently clear from the above text. Furthermore, Arsad et al. (2015) explains that in environmental conservation, the Maqasid understanding for the waste minimisation and protecting the environment can be envisioned from strict adherence to Qur'anic injunction, where Lord Almighty proclaims, "and cause not corruption upon the earth after its reformation, and invoke Him in fear and aspiration. Indeed, the mercy of Allah is near to the doers of good (Al Qur'an 7:56).

According to legal maxims (qawa'id al-fiqhiyyah) from Maqasid perspective, it is a general maxim, which says, La Darara wa la Dirar, and that means, "Harm shall not be inflicted nor reciprocated". This maxim indicates the importance to remove all kinds of harm especially to human, environment and society (Arsad et al., 2015).

\section{The Way Conventional Businesses Respond to the Sustainable Paradigm}

According to Medel-González et al. (2013) in the 1980s, the awareness has already grown on conserving the very delicate nature due to relentless and reckless economic and infrastructural development, where any further checkless development may in fact cause severest damage to the (already) fragile system. This gave rise to appreciate a sustainable appraisal from all spectrums of society, name, economic, society and the nature. Likewise, the corporate sustainability (CS) gained the momentum to address 'all' stakeholders in place of previous shareholders' view, through delicately and proactively balancing the economic, environment and social domains (Hubbard, 2009; Medel-González et al., 2013) by engaging a multidimensional performance measurement system in corporate and governance sector. The multidimensional performance measurement (MPM) includes business strategies, financial returns, customer's satisfaction, stakeholder's interest, internal processes and above all the human factor (Epstein and Marie-Josée 2001, as cited by Medel-González et al., 2013). To address this MPM, Kaplan et al. (1992) proposed a Balanced Scorecard (BSC) system, which further is designed towards a sustainably enhanced SBSC to reflect the holistic issues related to corporate sustainability (Erechtchoukova et al., 2013).

And again Becker (2005) explains that to understand the sustainability, revisiting the nature is essential, as the author centres his understanding based on 'Web of life' - as enlightened by Capra (1996). In this regard, understanding the power of resilience, the absorptive notion of nature is important, as elucidated by Becker (2005), citing Conway et al. (1990) and Holling (1973). Resilience implies adaptability, and lack of it results in fragility. 
Holling (1973), as cited by Becker (2005), explains that greater adaptability may provide a better chance of recovery after stress and shocks. And furthermore, collaboration is important aspect in understanding and appreciating the sustainable paradigm (Becker, 2005; Capra, 1996). Next, Becker (2005) stressed the notion of inclusivity as seen imperative by Norgaard (1994). In relation to inclusivity, the significance of community involvement is equally an important aspect in attaining sustainable development.

Becker (2005), quoting Smith et al. (1998), equates inclusivity with equity in social systems, and it includes life expectancy, literacy and affordable housing. But in pursuing such narrative, society need to address the issue of uncertainty. As Becker (2005) puts it, "Humans are also affected by uncertainty, despite their ability to manipulate their environment". So society can expect uncertainty and the chances of its occurrence can affect the society seriously. Though uncertainty an aspect one cannot ignore, but the notion of futurity can explain that the sustainability and sustainable development in reality implies continuity as well as change for the better. These aspects provide a better futurity, 'which addresses the needs of future generations i.e., inter-generational equity' (Becker, 2005). This final aspect requires sustainable community to adapt to flexibility to changing environments (Smith et al., 1998) as quoted by Becker (2005). In conclusion Becker states that the evaluation of sustainable development can assess the societal needs, and resources, 'through repetition, responsiveness to changes' and through a holistic approach in addressing the above issues.

According to Mohammad (2010), capitalistic thinking vs. issue of sustainability are often incompatible in terms of assessing the paradigmatic inconsistencies. As the author Mohammad (2010) quotes (Magel, 2001), that the freemarket theories may miss the mark to implement the conventional 'sustainable development theory' or in other words may fail to realise the sustainability goals. And permitting to Rogers (2000) as noted by Mohammad (2010), the base of sustainability depends on socio-economic-environmental necessities, but the capitalism strives on capitalists' welfare and values, discounting social ones. In the last two centuries, the run towards capitalistic encroachment has resulted in agonising eco-degradation level, as explained by Liodakis (2000) and Mohammad (2010). In addition, the drive towards capitalism has an equal clout on socio-economic deprivation to an unprecedented level, where equitable growth or idea of resource democratisation is absolutely missing, but these are the standard yardsticks of sustainable environment.

\section{Understanding the Sectoral Convergence}

How three segments of sustainable paradigm are addressed in Islamic framework, is presented in following sections.

\subsection{The Importance of Environmental Protection in Islam}

In Islamic paradigm, Muslims are treated as the trustees of the safe keep of the environment, as understood from $\mathrm{Al}$ Qur'an (5: 64), and equally stated by Ahmadi (2016), that Allah may not like transgression and corruption in and of the environment. And further similar injunction repeats in following words, "It is He Who has brought into being gardens - the trellised and untrellised - and the palm trees, and crops, all varying in taste, and the olive and pomegranates, all resembling one another and yet so different. Eat of their fruits when they come to fruition and pay His due on the day of harvesting. And do not exceed the proper limits, for He does not love those who exceed the proper limits" (Al Qur'an 6:141). And Lord also warns to protect the nature in following words, "... and make no mischief on earth after it has been set in good order. That is to your own good, if you truly believe" (Al Qur'an 7:85).

Humans are mere beneficiary and not the owner to do whatever they want through free will, and that's the Islamic position of humans on earth (Ahmadi, 2016). Humans need to ensure peace and harmony with nature, and with every individual, every social element, or environmental or economic interest, and need to conform to sustainable understanding. And the relationship with nature in an Islamic worldview has to be even stricter than conventional wisdom as explained by Hasan (2006). On resource allocation and efficiency, Lord proclaims, "We sent down water from the sky in right measure, and caused it to stay in the earth... We caused gardens of date-palms and vines to grow for you wherein you have an abundance of delicious fruits... and from them you derive your livelihood. (Al Qur'an 23: 18-20). So according to Ahmadi (2016) the verses eventually confirm the importance of fulfilling the heavenly orders, and that is to take care of the environment at the very onset. 


\subsection{The Importance of Maqasid in Economic Development}

Islam clarifies the economic importance through the following Qur'anic injunctions, "And there is not a thing but that with Us are its depositories, and We do not send it down except according to a known measure" (Al Qur'an 15:21). Islam encourages accommodative sustainable economic and business model for thriving the economic development, rendering Ahmed et al. (2017). The Islamic notion goes beyond the conventional norm, according to Hasan (2006). In addition, Aydin (2015) states that in comparison to conventional social business platform, the Islamic alternative understanding and wisdom is more sustainable, exceedingly demanding and profoundly applicable both in terms of theoretical and practical significance.

Islamic paradigm encourages healthy business and economic activity in line with Maqasid element, and that is sustained through understanding the societal context and benefits, where minimum level of affliction to anyone is commandingly vital (Chapra et al., 2008). The economic activity will enhance to upkeep with fulfilment of basic needs, as well as the realisation of equitable distribution of income and wealth, and this can be attained through moral wellbeing, and adequate training to gain in the long run. If these healthy economic activities cannot flourish, it may lead to decline in civilisational development and may harm the true existence of human and nature (Chapra et al., 2008). The hale and hearty economic activities will help ensuring socio plus economic justice with communal peace in society, as per the said authors.

In line with that notion, Sadeq (1996) clarifies that zakat is a solid instrument for the Islamic economic framework towards a sustainable grassroots human development in an Islamic entity. It also gives asnaf (zakat recipient according to Qur'an and hadith) a sense of self-reliance and making oneself out of poverty, if one truly wants to. And that fits-in first of all, the protection of life and health, as well as protection of wealth and progeny, as well as faith, and ultimately intellect, as per Maqasid developments. This is also in line with the economic or financial sustainability in pursuit of sustainable development (Yumna et al., 2011). Furthermore, in the end note, Islam promotes a balanced sustainable measure to overcome any economic or social woes, or likewise (Hasan, 2006; Sadeq, 1996).

This in turn will augment the socio-economic environment to be in line with sustainable development and social security measures, as seen in par with contemporary western society. This development from Islamic perspective can ensure enhanced social justice (Ibrahim, 2015; Sarif et al., 2009). The Lord Almighty commands in the Holy Scriptures, "The believing men and believing women are allies of one another. They enjoin what is right and forbid what is wrong and establish prayer and give zakat and obey Allah and His Messenger. Allah will have mercy upon them. Indeed, Allah is Exalted in Might and Wise" (Al Qur'an 9:71). So the practising Muslims will be humbly submissive to Allah and perform prayers with sincerity and pay zakat dues in time (Al Qur'an 23:1-4).

\subsection{The Social Aspect in Maqasid}

The Islamic viewpoint on the above scenario is that, an Islamic entity needs to ensure a clean, honest, continually encouraging good deeds and make a disciplined life, and at all-time be free from any sort of wastage, as clarified by Ahmadi (2016). To pursue such well-mannered life and behaviour, knowledge expansion will assist in achieving that desired objectives, because this refinement in knowledge expansion will enlighten to have communal understanding or public participation called 'shura' (Moten, 2013). And as a result, the society will better comprehend the Divine inscriptions, and will absorb the spiritual dimension as well as its significance in a more astute manner. As a result, the ethical and moral development becomes equally important in appreciating the Maqasid implementation towards a civilising society (Chapra et al., 2008; Sulayman 2014).

This moral refinement will help the society conserve 'adl' or justice in place of 'fasad' or calamity or environmental degradation (Ahmadi, 2016). And the adl or justice can be attained when the poor, downtrodden and marginalised people are addressed effectively and cared through the zakat, sadaqat and waqf system in upbringing their status in society. Ensuring the robustness of these policy prescriptions can have the five basic Maqasid requirements fulfilled better than before due to such developments. And this may require institutional development through innovation (Ijtihad) and governance and practicing zuhd (avoidance of unnecessary spending) and ihsan i.e. a sense of social responsibility, explains the learned author.

\section{Assessment of Maqasid and SD in the Context of Asnaf Development}

Zakat plays an important role in asnafs' sustainability (Ali et al., 2014). While prompting zakat's growth possibility in the realm of productivity, Ibrahim et al. (2014) upheld that zakat can be a way forward towards empowerment in 
line with Maqasid fulfilment, towards alleviation of poverty and reducing the income gap. The authors accept zakat's expansion and growth potential as business capital. According to Ibrahim et al. (2014) this development can generate progressive income and enlarge the economy through emancipation of life, value and quality. That is why Islam places the zakat at the forefront to address the issue of poverty and socioeconomic welfare in an Islamic framework (Ibrahim et al., 2014, quoting Ataul Haq Pramanik, 1990). In earlier research findings, it was observed that poverty and wellbeing may be interconnected (Ahmad et al., 2016), though more considerations are necessary (Rojas, 2008, as quoted by Ahmad et al., 2016).

Ibrahim (2015) elaborates that Zakat is a God gifted system bestowed for mankind towards establishing a truly sustainable development. It is like a 'collective social security scheme for mutual help' as well as sympathy in an Islamic economic framework. Ariyani (2016) elucidates that zakat is an effective strategy in an Islamic framework towards poverty alleviation. The author (Ariyani, 2016) further states that, zakat is actually a practical sustainable mechanism to overcome the socio-economic gap in a Muslim society.

Essentially zakat (alms) is welfare oriented economically viable and sustainable measure towards the peaceful existence of the humankind (Ibrahim, 2015). This establishment will ensure social order, which is part of social sustainability, according to the said author. This enhancement will create collective social security and long term benefits to peaceful existence of human society. The structure of zakat will improve the sharing and caring attitude, towards a more financial stable as well as a healthier society.

\subsection{Appreciating due Diligence of Asnaf Development}

According to Kakwani (2006), as reported by Ahmed et al. (2017) that it is important to asses poverty not based on material deprivation, such as income, but need to be assessed through the issue of lack of health, lack of education, their coping with risks and vulnerability, powerlessness or social exclusion. So when allocating the zakat fund towards the poverty alleviation, it's important to improve their status quo, as duly agreed by most of learned jurists of all time (Ahmed et al., 2017). And according to Imam Nawawi as reported by (Ahmed et al., 2017; Bakar et al., 2011), the zakat proportions allocated for the needy and the poor may need to take into account the recipients' skills and present living condition. If assisted based on skills enhancement, then that will be a good starter in moving that needy out of asking basket in future, and that will be most deserving episode. As per Ahmad et al. (2016) even if through a concerted effort the incidence of poverty can be reduced considerably, but further still required because the shape and the form of poverty may change due to varying of dimensions. Ahmad et al.'s (2016) further explains, 'many problems and challenges still exist'.

Ahmed et al. (2017) reported that to measure poverty, it may be preferable to assess the poor's consumption basket, and that of the self-employed, as explained by Abdullah et al. (2012), because it may often be difficult to assess the informal sector's income. And furthering to that discussion, Ahmed et al. (2017) further states that, the satisfaction of basic human needs such as food, shelter, clean running water, sanitation, clothing, education and health care is rather the overriding objective of any development policy, as equally narrated earlier by Alkire \& Santos (2010). And as per Bakar et al. (2011), an empowerment mechanism in zakat distribution could bring long term benefit, same note was observed by Ibrahim et al. (2014).

\subsection{The Significance of Developing the Zakat Base to Achieve Maqasid Al Shariah}

Sarea (2012) argues that effective zakat (alms) distribution to the prescribed eight categories can lead to economic growth through sustainable development in terms of redistribution of wealth and bridging the income gap. The author (Sarea, 2012) elaborates Ibn Ashur's description on 'Maqasid al-Shariah al-Islamiyah (Objectives of Shariah) as the mother of Islamic economics and science, and zakat as like an act of dedicated worship expressing a Muslim's gratitude for Allah's financial gifts (Awang et al., 2012). According to Sarea (2012), Kahf (1999) and Bakar et al. (2010), the objective of zakat is none other than just to ensure socio-economic justice.

Effective zakat implementation will render huge benefits to the society, like multiplier effect on employment and incomes, as per Sarea (2012). And more importantly, poverty can be gradually eliminated through effective and empowered management (Sarea, 2012). Therefore, the significance of effective zakat implementation can assist the economy to achieve its Maqasid in due course. The author suggests that zakat can assist all the three main elements of production, namely labour, capital and natural resources. In other words, that's the prerequisite of sustainable agenda or the Maqasid of an Islamically inclined economy. Zakat can also be a monetary instrument in regulating 
the inflation or the economy, through the device of supply and demand of money. Sarea (2012) states in circumstances, "...management of Zakat ... (can be performed) to reduce the inflation rate by imposing Zakat (on givers) to be paid to recipients".

The authors (Ahmed et al., 2017; Bakar et al., 2011) regard zakat as a social insurance policy and a potent redistributive mechanism towards inequality reduction, that is available to Ummah (the believers), though the prospect is still untapped. And this inequality can be well measured by education index, health index and standard of living index and so on (Ahmed et al., 2017). In actual fact, though there are discrepancies in defining who are rather poor and who are in actual need, because of differences among Muslim jurists, but nevertheless, not having enough to eat or to cloth or a decent shelter, in any environment or economy, warrants a thorough recheck on adequate rehabilitation (Ahmed et al., 2017; Bakar et al., 2011). These issues provide urgent need to assess the situation, may be through multidimensional indexes such as MPI (multidimensional poverty index), as stated by (Alkire \& Santos, 2010; Ahmed et al., 2017). But Becker (2005) ascertains that the correct evaluation method in regards to sustainable development may depend on setting goals and objectives, and also on the resource availability as well as the concerned nature of the stakeholder. So these commendations are fittingly important for asnaf development in line with Maqasid or sustainable paradigm.

\section{Proposed Conceptual Framework}

Through systematic literature review and content analysis, the study's research methodology aims to enlighten that the classical Maqasid Al Shariah, as prescribed by Imam Ghazzali and Imam Shatibi, which is actually more like a revolutionary human development model as per Oladapo et al. (2017), is more encompassing than just mere Sustainable model as understood in the conventional terms. The note has been explained and detailed in the review, and therefore, the welfare of asnaf truly depends on understanding and appreciating both the paradigm in assessing the true progress and also to appreciate the mechanism to sustain, and understand their true abilities. Hence, the proposed framework is presented below.

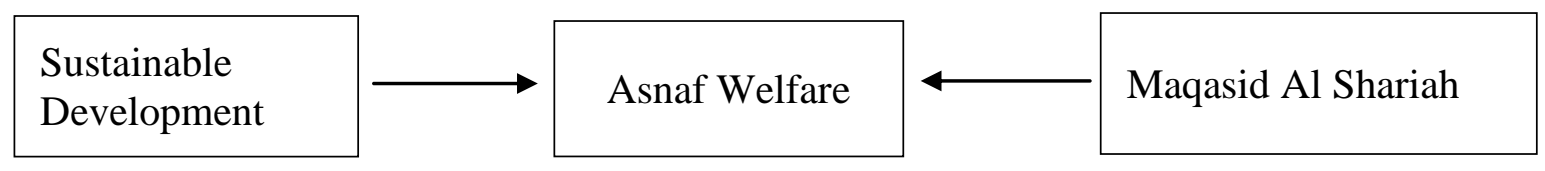

Figure 1: Proposed Mutual Framework for Asnaf Development

In true essence, the protection of faith, life, intellect, progeny or wealth, which is the exegesis of Maqasid $\mathrm{Al}$ Shariah, truly embraces the three dimensional spectrum of sustainability, and that is the economic, social and environment as understood by many and explained in detail in the study. Therefore, the mutual convergence and mutual existence may truly benefit in uplifting the status of asnaf, and can bring a breakthrough in asnaf development and empowerment.

\section{The Contemporary Discussions and Recommendations}

According to a famous narration from the holy Prophet (pbuh), as explained by Bakar (2011), the Lord Almighty will send a reformer (Tajdid) every century for human guidance. So according to the said author, the Maqasid and the Tajdid, as understood by Ibn Khaldun in the thirteenth century, both have very contemporary prominence in solving perennial matters. Because the beauty of Islam is not only in the way of life (Deen), but also as a constant evolver of dynamism in civilisation. Therefore, the issue of Islamic revivalism encompasses all embracing societal manifestations.

Bakar (2011) further states that, Shariah without the Maqasid element will be lost in time and space battle in answering contemporary questions. The issue with contemporary time and space is, that only the "material growth, development and progress' stand the effort, whereas human welfare and dignity takes a back seat. As per Bakar (2011), a person or a nation or a society is judged based on three material elements, i.e. growth, development and progress - ignoring the human welfare or human dignity in mind. In author's own words, "He evaluates and grades his fellow men according to the degree of their success or failure in achieving growth, development, and progress. Thus, we used to have the groupings 'advanced' or 'developed' nations, 'developing' and 'underdeveloped' nations or societies, or 'progressive' and 'backward' countries and societies". Due to such narrow and distorted thoughts of 
developments, society experiences extreme deprivation and finally a huge contradiction becomes eminent. This so called inconsistent and distorted development made the Red Indians in America go extinct, while pursuing the drive towards the Wild West was observed. Similar fate happened to the natives of Australia and New Zealand. And as a result of massive destruction to mankind, and also to the fragile nature - that was sadly observed even in the very recent past through natural and political calamities.

As Bakar (2011) points out, "Contemporary human civilisation is rich and advanced in scientific and technical knowledge, but poor ... in moral and spiritual knowledge and wisdom. Consequently, we are superb at solving even the most complex of scientific ... problems ... but we are utterly hopeless when it comes to solving the most basic of human problems". In chasing such flawed progression the institutionalised racism has become very inappropriately the norm, according to Bakar (2011).

Therefore, equilibrium in life, that is ensuring 'justice while advancement' would be best way forward as understood by the sustainability induced mechanisms, and likewise Islamic Maqasid principles rather excels way ahead in this regard. In Islam, the concept 'itidal' that relates to justice and peace, is inherently related to harmony with nature (Bakar, 2011). Therefore not having equilibrium (i.e. away from the norm) resembles as pain and discomfort in human civilisation, which might need urgent ramification.

In appreciating the understanding of Maqasid Al Shariah, it is important to analyse the legal rules (Ahkam), the value of Ijtihad (evaluation of the legal maxims, and a polar opposite to Taqlid, which is indiscriminate imitation), and the fatwas (a ruling by a learned expert) so as to realise the broader goals and purposes of the Shariah (Kamali, 2011). In the past, due to undue importance that was sadly given to Taqlid at the beginning, and hence Maqasid was inappropriately and unfortunately left marginalised for centuries, but auspiciously Maqasid gained momentum since the thirteenth century, when, Imam Al Ghazzali (Raa), Imam Al Shatibi and such noble saviours started researching in deeper Fiqhi (the philosophy of Islamic law) matters to recognise the contemporary issues through inductive method of exploration, as elaborated by Kamali (2011).

But essentially, the gaining prominence of Maqasid, is duly and timely acknowledged again in the twentieth century, after the vacuum created by newly minted Muslim territories, which were under the despise colonial rule even in the recent past (Kamali, 2011; Moten, 2013). And the reason for importance can be explicated from the following passage, "Maqașid are inherently dynamic by comparison and open to growth in tandem with changing conditions, just as they also strike a closer note with the contemporary human rights discourse" (Kamali, 2011).

In matter of fact, Maqasid gained the due diligence because of hidden Hikmah (benefit or wisdom) or Maslahah (public interest) in relevance to civilizational renewal (Tajdid Hadari) as explained by various scholars and summarised by Kamali (2011). Here authors discuss Al Fitrah (natural law or human nature) of mankind, and that is, the human propensity is to accept that is good and reject that is wrong in society in considering the civilisational renewal aspect of Maqasid. Because the Qur'an desires human to be the torchbearer of huda wal rahmah (guidance and blessing as stated in verse 10:57 of Al Qur'an) under the supreme assistance of the Prophet (pbuh) as the blessing of mankind, rahmatullil alamin (Al Qur'an 21:107). To ensure the blessings is endured, the Prophetic ruling can be transformed for a better outcome, 'but' only for the maslahah (public benefit) of the ummah (for the whole community), as explained in detail by Kamali (2011). In Maqasid accomplishments, human dignity, issue of equality, justice and fair treatment are important objectives while adhering to moderation and justice (Al Qur'an 2.143: Kamali, 2011). Ibn Rushd (d. 1198, as noted by Kamali, 2011) entails that, these can be accomplished only through higher ethical, moral and spiritual upliftment and devotion, through a holistic understanding as explained by Nasr and reported by Moten (2013).

\section{Concluding Remarks}

The sustainability paradigm and the Maqasid is more in line with wider ethical inclination, and for the benefit of 'all' the stakeholders. This is in sharp contrast to the pure capitalistic understanding of only to realise and ensure the benefits of the 'shareholders'. The similarities in SD and Maqasid may have positive effect, and can assist the poor and especially the asnaf in building a better future. Asnaf requires an overall upliftment strategy, towards a more holistic development of social, economic and their environmental concerns in addressing the systematic and concerted effort of making them out from any further deprivation. The paper attempted to explain that the conventional sustainable paradigm is more attuned to Maqasid al Shariah, but as many authors did clearly state that 
the Islamic stance is more holistic and wholesome then the most recent consideration in SD and so on, therefore its quite ascertaining that more research, understanding and exploration in this regard becomes due. The study textures that this 'long due' convergence is extremely important in greater understanding that Islam is understood as rather a way forward towards economic, personal, societal, religious, environmental harmony and peace. And more importantly, it's encouraging that the poverty alleviation and solving the status of asnaf and similar, are given due share in this Maqasid fulfilment. It is more noticeable, that only through a sustained development policy; asnaf can be better off, and not necessarily through any ad-hoc measures, as dismally and openly remitted by different zakat jurisdictions.

\section{Kind Acknowledgement}

A shorter version of this paper was presented at the 2nd UUM Islamic Business Management Conference, 4-5 July 2018, in Kuala Lumpur, Malaysia. The authors are indebted to Dr Md. Mahmudul Alam of UUM for valuable suggestions and guidance.

\section{References}

Abdullah, N., Yusop, M. M. M., \& Awang, C. O. H. (2012). A technical note on the derivation of zakat effectiveness index (ZEIN). International Journal of Economics, Management and Accounting, 20(1), 75 .

Abubakar, Y. S. (2016). Corporate social responsibility of Islamic financial institutions: a look from the Maqasid Al-Shariah (purpose of Shariah) approach. Business and Economics Journal, 7(255), 1-4.

Ahmad, N. F., Mansor, M., \& Paim, L. (2016). Income Poverty and Well-Being among Vulnerable Households: A Study in Malaysia. Asian Social Science, 12(2), 195.

Ahmadi, M. (2016). Sustainable Development-Islamic Perspectives, www.ijaur.ir.

Ahmed, F., Siwar, C., \& Idris, N. A. H. (2011). Impact of microcredit programme for the rural poor: Evidence from Amanah Ikahtiar Malaysia. Research Journal of Applied Sciences, 6(5), 290-294.

Ahmed, B. O., Johari, F., \& Abdul Wahab, K. (2017). Identifying the poor and the needy among the beneficiaries of zakat: Need for a zakat-based poverty threshold in Nigeria. International Journal of Social Economics, 44(4), 446-458.

Alam, M. M., Hassan, S., \& Said, J. (2015). Performance of Islamic microcredit in perspective of Maqasid Al-Shariah: A case study on Amanah Ikhtiar Malaysia. Humanomics, 31(4), 374-384.

Alam, M. M., Shahriar, S. M., Said, J. (2018). Waqf as a Tool for Rendering Social Welfare Services in the Social Entrepreneurship Context, GJAT, 87.

Ali, I., \& Hatta, Z. A. (2014). Zakat as a poverty reduction mechanism among the Muslim community: Case study of Bangladesh, Malaysia, and Indonesia. Asian Social Work and Policy Review, 8(1), 5970.

Al-Jayyousi, O. R. (2015). Rethinking Sustainability: Islamic Perspectives, Climate Change, EcoIslam, Sustainable Development.

Alkire, S., \& Santos, M. E. (2010). Acute multidimensional poverty: A new index for developing countries, Oxford Poverty \& Human Development Initiative (OPHI) working paper \# 38. 
Anto, M. B. (2011). Introducing an Islamic human development index (I-HDI) to measure development in OIC countries. Islamic Economic Studies, 130(542), 1-54.

Ariyani, N. (2016). Zakat as a Sustainable and Effective Strategy for Poverty Alleviation: from the Perspective of a Multi-Dimensional analysis. International Journal of Zakat, 1(1), 88-106.

Arsad, S., Ahmad, R., Fisol, W. N. M., Said, R., \& Haji-Othman, Y. (2015). Maqasid Shariah

in Corporate Social Responsibility of Shari'ah Compliant Companies. Research Journal of Finance and Accounting, 6(6), 239-247.

Awang, R. N., \& Mokhtar, M. Z. (2012). Comparative Analysis of Current Values and Historical Cost in Business Zakat Assessment: An Evidence from Malaysia. International Journal of Business and Social Science, 3(7).

Aydin, N. (2015). Islamic social business for sustainable development and subjective

wellbeing. International Journal of Islamic and Middle Eastern Finance and Management, 8(4), 491-507.

Azhar Rosly, S. (2010). Shariah parameters reconsidered. International Journal of Islamic and Middle Eastern Finance and Management, 3(2), 132-146.

Bakar, M. H. A., \& Abdghani, A. H. (2011). Towards achieving the quality of life in the management of zakat distribution to the rightful recipients (the poor and needy). International Journal of Business and Social Science, 2(4).

Bakar, N and Rashid, H. (2010) "Motivations of Paying Zakat on Income: Evidence from Malaysia”. International Journal of Economics and Finance, Vol. 2, No. 3.

Bakar, O. (2011). The Place and Role of Maqasid Al-Shari'ah in the Ummah's 21st Century Civilizational Renewal. Islam and Civilisational Renewal, 2(2), 285.

Becker, J. (2005). Measuring progress towards sustainable development: An ecological framework for selecting indicators. Local Environment, 10(1), 87-101.

Brugmann, J. (1997). Is there a method in our measurement? The use of indicators in local sustainable development planning. Local Environment, 2(1), 59-72.

Brundtland, G. H. (1987). Our common future: Report of the World Commission on Environment and Development. World Commission on Environment and Development.

Capra, F. (1996). The web of life: A new scientific understanding of living systems. Anchor Books.

Carney, D. (2003). Sustainable livelihoods approaches: progress and possibilities for change (p. 64). London: Department for International Development.

Chapra, M. U. (2008). Ibn Khaldun's theory of development: Does it help explain the low performance of the present-day Muslim world?. The Journal of Socio-Economics, 37(2), 836-863. 
Chapra, M. U., Khan, S., \& Al Shaikh-Ali, A. (2008). The Islamic vision of development in the light of maqasid al-Shariah (Vol. 15). Iiit.

Conway, G. \& Barbier, E. (1990) After the Green Revolution: Sustainable Agriculture for Development (London: Earthscan).

Dar, H. A. (2004). On making human development more humane. International Journal of Social Economics, 31(11/12), 1071-1088.

Dusuki, A. W., \& Abdullah, N. I. (2007). Maqasid al-Shariah, Maslahah, and corporate social responsibility. American Journal of Islamic Social Sciences, 24(1), 25.

Dusuki, A. W., \& Bouheraoua, S. (2011). The framework of Maqasid al-Shari'ah and its implication for Islamic finance. Islam and Civilisational Renewal, 2(2), 316.

Elkington, J. (1998). Partnerships from cannibals with forks: The triple bottom line of 21stcentury business. Environmental Quality Management, 8(1), 37-51.

Epstein, M. J., \& Roy, M. J. (2001). Sustainability in action: Identifying and measuring the key performance drivers. Long range planning, 34(5), 585-604.

Erechtchoukova, M. G., Khaiter, P. A., \& Golinska, P. (Eds.). (2013). Sustainability

appraisal: quantitative methods and mathematical techniques for environmental performance evaluation. Springer Science \& Business Media.

Hamilton-Peach, J., \& Townsley, P. (2004). An IFAD sustainable livelihoods framework. International Foundation for Agricultural Development (IFAD).

Haq, A., Ashraf, M., \& Farooq, M. O. (2017). Zakat, Persistence of Poverty and StructuralIncidental Segmented Approach: A Survey of Literature, SSRN, Journal of Islamic Financial Studies, 3(1).

Hasan, Z. (2006). Sustainable development from an Islamic perspective: Meaning, implications, and policy concerns.

Hassan, A., \& Shahid, M. A. (2010). Management and development of the awqaf assets. In

Proceedings from the Seventh International Conference-The Tawhidi Epistemology: Zakat and Waqf Economy, Bangi (pp. 309-328).

Holling, C. S. (1973) Resilience and stability of ecological systems, Annual Review of Ecology and Semantics, 4, pp. 1-24.

Hubbard, G. (2009). Measuring organizational performance: beyond the triple bottom line. Business strategy and the environment, 18(3), 177-191.

Ibrahim, P., Ab Rahman, A., \& Basir, S. A. (2010). Sustainable economic development:

Concept, principles and management from Islamic perspective.

Ibrahim, P., \& Ghazali, R. (2014). Zakah as an islamic micro-financing mechanism to 
productive zakah recipients. Asian Economic and Financial Review, 4(1), 117.

Ibrahim, S. M. (2015). The role of zakat in establishing social welfare and economic sustainability. Jeddah: IRTI-IDB.

Kahf, M. (1999). The principle of socio-economic justice in the contemporary fiqh of zakat. The Iqtisad, University Islam Indonesia

Kakwani, N. and Hyun, H.S. (2006), "New global poverty counts”, Working Paper No. 29, UNDP International Poverty Centre, September, Brasilia.

Kamali, M. H. (2011). Maqasid al-shari'ah and ijtihad as instruments of civilisational renewal: a methodological perspective. Islam and Civilisational Renewal, 2(2), 245.

Kamarrudin, R., \& Samsudin, S. (2014). The sustainable livelihoods index: A tool to assess

the ability and preparedness of the rural poor in receiving entrepreneurial project. Journal of Social Economic Research, 1(6), 108-117.

Kaplan, R. S., and Norton, D. P. (1992). The Balanced Scorecard: Measures That Drive Performance, Harvard Business Review, 71-79.

Laldin, M. A., \& Furqani, H. (2013). Developing Islamic finance in the framework of maqasid al-Shari'ah: Understanding the ends (maqasid) and the means (wasa'il). International Journal of Islamic and Middle Eastern Finance and Management, 6(4), 278-289.

Liodakis, G. (2000). Environmental Implications of International Trade and Uneven

Development: Toward a Critique of Environmental Economics. Review of Radical Political Economics. 32(1): 4079.

Magel, H. O. L. G. E. R. (2001). Access to land and Security of tenure as a Condition for

Sustainable Human Development. In proceedings of Habitat Professionals Forum, Istanbul (Vol. 5).

Medel-González, F., García-Ávila, L., Acosta-Beltrán, A., \& Hernández, C. (2013).

Measuring and evaluating business sustainability: development and application of corporate index of sustainability performance. In Sustainability Appraisal: Quantitative Methods and Mathematical Techniques for Environmental Performance Evaluation (pp. 33-61). Springer, Berlin, Heidelberg.

Mili, M. (2014). A Structural Model for Human Development, Does Maqāṣid al-Sharī‘ah Matter! Islamic Economic Studies, 22(2), 47-64.

Mohammad, M. T. S. H. (2010). Principles of sustainable development in Ibn Khaldun's economic thought. Malaysian Journal of Real Estate, 5(1), 1-18.

Moten, A. R. (2013). Islam and civilisational renewal: the case for "sacred science". Islam and Civilisational Renewal, 4(4), 562-578.

Nadzri, F. A. A., Rahman, A., \& Rashidah \& Omar, N. (2012). Zakat and Poverty

Alleviation: Roles of Zakat Institutions in Malaysia. International Journal of Arts and Commerce, 1(7), 61-72. 
Nalla, Z. (2011). Corporate social responsibility (CSR) in Malaysia with reference to the Maqasid. Islam and Civilisational Renewal, 2(2), 384.

Naqvi, S. N. H. (1981). Ethics and economics: An Islamic synthesis (Vol. 2). islamic Foundation.

Norgaard, R. (1994) Development Betrayed (London: Routledge).

Nouh, M. (2012). Sustainable Development in a Muslim Context. Faith Values and Education for Sustainable Development, 39.

Obaidullah, M., \& Shirazi, N. S. (2014). Integrating Philanthropy with Microfinance: Models of Community Empowerment. In Social Impact Finance (pp. 75-96). Palgrave Macmillan, London.

Oladapo, I. A., \& Ab Rahman, A. (2017). Maqasid Sharī 'Ah: the drive for an inclusive human development policy. Jurnal Syariah, 24(2).

Pramanik, A. H. (1990). Development and Distribution in Islam. Petaling Jaya: Pelanduk Publications.

Rasool, M. S. A., Yusof, M. A. M., \& Amran, S. A. T. S. (2018). Enhancing Wellbeing of Low Income Household: Perspective of Zakat Recipients. Advanced Science Letters, 24(6), 4116-4120.

Redclift, M. (1989). The environmental consequences of Latin America's agricultural development: some thoughts on the Brundtland Commission report. World Development, 17(3), 365-377.

Rogers, R. A. (2000) Survey: The Usury Debate, the Sustainability Debate, and the Call for a Moral Economy. Ecological Economics. 35(2), 157-171.

Rojas, M. (2008). Experienced poverty and income poverty in Mexico: A subjective wellbeing approach. World Development, 36(6), 1078-1093.

Sadeq, A. M. (1996). Ethico-economic institution of Zakah: an instrument of self-reliance and sustainable Grassroot development. Humanomics, 12(2), 47-69.

Sarea, A. (2012). Zakat as a benchmark to evaluate economic growth: An alternative approach. International Journal of Business and Social Science, 3(18).

Sarif, S., \& Kamri, N. (2009). A theoretical discussion of zakat for income generation and its FIQH issues. Shariah Journal, 17(3), 457-500.

Smith, A. (1937). The wealth of nations [1776].

Smith, M., Whitelegg, J. \& Williams, N. (1998). Greening the Built Environment (London: Earthscan).

Soofi, A. (1995). Economics of Ibn Khaldun Revisited. History of Political Economy, 27(2), 387-404. 
Strange, T. \& Bayley, A. (2008). OECD insights sustainable development linking economy, $\quad$ society, environment: Linking economy, society, environment. OECD Publishing.

Sulayman, H. I. (2014). Values-based curriculum model: A practical application of integrated

'maqasid al-sharia'for wholeness development of mankind. Procedia-Social and Behavioral Sciences, 123, 477484.

Yumna, A., \& Clarke, M. (2011, December). Integrating zakat and Islamic charities with microfinance initiative in the purpose of poverty alleviation in Indonesia. In Proceeding 8th International Conference on Islamic Economics and Finance, Center for Islamic Economics and Finance, Qatar Faculty of Islamic Studies, Qatar Foundation. 
